\title{
抄譯
}

\section{粘度の工業的測度としての絕對粘度係數の勃用に就いて (II)}

M. Woog, Peintuers Pigments Vernis, Sest mmbre, 1929, 968.

照憵 表

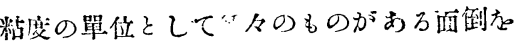
免れるために、䔬なるシステムの間の照㫿表 が提悹されげ

工業的粘度测定の諸法は全く任意的のもの でむろ。デュュ゚イ氏 Du;ouy: Recherches expérimentales sur la viscosité des huiles. Faculté des Sciences. Paris, 1923. に由万そ一つの システムから他のシステムへの換算式に由る と大なろ䛤差え示して居る

絕劉䉼度係數の使用

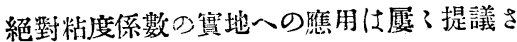
れその探用は事筫上に於い:て喜ばしい傾向占 磪示して居ろのであろが絕對粘度の係數”と 云子言亲は物理學者に取つては具象的では中 ろが實際家に取つては抽象的でむる、そこで 粘度係數を每本方糎に封するダイン数に等筫 として現はすことな誟へた、然し之れは間違 ひであろ、何となれば粘度係數は表面働く力 ではなくて運動の量であろからである、粘度 ね每平方糎ダィンで表は寸ことば般化さら れなかつけけれどる、表示法として缺陷ある にも拘らず屡了出會すのである

$$
\text { ポ } 1 \text { ズ Poise }
$$

ポアズキュ Poiceuille 氏の名からポイズ “Poise”(譬査註. 佛蘭西讀みにすればポアブ)
そ云ふ名稚が提議されけ、提案萖は英國の技 師マウントフォード・ディーレーR. M. Deley氏 である

マルそル，ブリヤン Brillouin 氏に化ると “ポイズ”は粘度の単位でなく粘度の實際的の

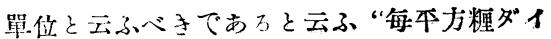

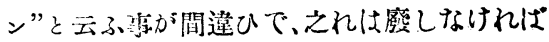
ならぬ、ポイブき云ふ約束上の言葉は C.G.S' で莸はしけ絕對粘度係數々云了云ひ現はしの 代りに嚴格に唯一的に用ふら事ができる、デ シポイブDecpoiseを主ふのはポイプの $\frac{1}{1 \sigma}$ を

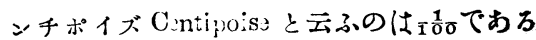

動力學的粘：日係數の使用

外國、特に工業界では、簡單のために動力學 的粘度係數 Viscosité cinematique (nc) を用子

$$
r_{\mathrm{ic}}=\frac{\eta}{d}
$$

こつにdは液体の密度であ万

$$
\begin{aligned}
& \text { クのディメンションは } \frac{\text { 力面皘 }}{\text { 間 }} \\
& \text { 祙の夫れ加速度 } \times \text { 時間 } \times \text { 長さである } \\
& \text { 寒地工業上に於いては愿了密度っ無視して } \\
& n_{\mathbf{c}}=\mathrm{Kt} \\
& \text { ストークス Stokes }
\end{aligned}
$$
の實際的單位としてストークスと云子名稱な 提案して居ろ

(石橋)

\section{液體皮赠形成の 理 論}

C. W. Foulk, Ind. Eng. Chem., Vol. 21, No. 9, p. 815.

液体の蒸發及び蒸溜に於いて泡 fo'm の形

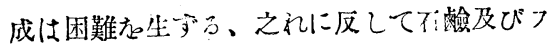
ローテーションに由万鈸石の灙别に於いては 泡の形成は有利である
ビール、ソーダ氷にあつては安定な泡の生 成は必要であつてシャンパン、ジンジャーメー ルに於いては泡は不安定でなければならか、 一般に 
（1）純粹な液体は泡か作らない、之れに就い ては理論は不明でサ:ぐ經驗の事實である

（2）液体中に不純物があると泡か生ず万、化 學的に云子々或万物啠が分子的に或は膠質的 に液体中に擴散して居万事が泡の形成には必 要である、加へけ物質の性質はあまり影響は ない即ち殆んご總ての物質が泡の形成な誘起 す万、然し之れ定量的に云子と大戀打相違 があ万、抱泡つ安定物度は色々であ万

(3) 定性的に云子ならば、加一られた物質が 正に或は頁に吸着せられて居万と云ふことは 問題でない、即ちいづれの昜合にも泡は生す ろ、正に吸着さられた Positively ads rrbed 物 筫は表面張力た低下せしめ、頁に吸着せられ た Negatively 物質は之れれ高めろが起泡性 そ表面張力の間には相關の關係ははいいうで ある

（4）或㮔の物筫は泡か破墥する力があり或 者は泡の生成か防ぐ、此れ等の起泡防止利 Antifoams の中少くをし若干のしのは正に吸 着せられけ:或は員に吸着せられた物質によっ て生しけ泡占破增し及はその形成方防止する 例へばカストル油は正に吸着せられケ:サボニ ンの泡艻双頁に吸着せられけ硫酸ナトリシム

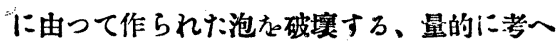
れば起泡防止劑は 1\%の1000分のいくつかで 有効なのである

以上迅ヘたやうな一般的の事賽の中には調 和し難いものがあるゃうに見へる一例へば站 んどすへてての可溶性物質がそのりよ照通な化 學的性質に無關係に泡え形成すると云子事々 そしてこの起泡性は表面張力及び溶解さ万物 筧の表面層に於ける濃度を液体主体中の濃度 その關係に製關係であると云ふこをなどが夫 れである、この一見矛盾したやうに見える事 筫はォストワルド及びスタイナーOstwald \& Steiner雨氏をして或液体の起泡性とその化學 的正數との間に關係を發見することは出來さ
うにむはいと云はしめるに至つたののである 著者し亦化學的の立場にのみ止つ一居万と この謎は解けはいのであるが一轉して起泡の 力學 mechanics of foam formation に注意死 向けて見ホのである

\section{液体皮膜形成の力學}

液体皮膜は二つの既成表面の液体の側に於 け万相互接近の結果であ万、例一巛゙液体表面 に於け万泡或は球狀皮膜は內部走通つて上显 し表面層の一部押し上げ擴張することに由 つて表面に近了氣体或は蒸氣の泡に由つて形 成さられ万泡の外面及面加 万平衡が得られ るまで一換言すれば二面が接近の運動か中止 するまで一液体はドレーン drainする

純液体の場合には二面の接近には中止す万 ことなく從つて泡は生じない、更に簡單な場 合汢二つの泡が或液体面の下で相互に接近す 万場合であ万、大抵の洨液に於いてかくの如 き泡は押しつけ合さ万る本くなる、純䉽液体 にあつては觸れることによつてつぶれる、從 つて皮膜は出來ない。今一つのよく知られた 例红固体の杵に二跨つて液体膜の生成寸万場合 であろ、シャボン玉丙吹くときのパイブの如 き之れである

バイプの圓形の口を石踰液の表面に持つて 行つて持ち上げると石簽水の液栍が持ち上げ られろ、この液柱の而上はパイプの圆形の栙 に由つて圍まれた液体の元の表面の部分であ ろ、之れが口の上に延びて行く液の上層或は 內層志成すしのである、下層或仆外層はバィ プの引上げに由つて生ず万液柱から出來る

この液柱はバイプね持ち上げると重力及び 表面張力の作用でひらけい洔計皿のやうな形 ねなしその口の首の所の断面が引張りに對し て抵抗方呈しないゃうになる 破壤される。 そうす万こ液桂の下部は落下し上部は表面張 カによつて上方に引かれパイプのロに皮膜の 下部の表面方作る 